\title{
PEMANFAATAN SALURAN IRIGASI UNTUK PEMBANGKIT LISTRIK PIKOHIDRO DENGAN GENERATOR DC SHUNT
}

\author{
Winarso $^{1}$, Wakhyu Dwiono ${ }^{2}$, Dian Nova K.H ${ }^{3}$ \\ Program Studi S1 Teknik Elektro, Universitas Muhammadiyah Purwokerto \\ Fakultas Teknik dan Sains, Universitas Muhammadiyah Purwokerto
}

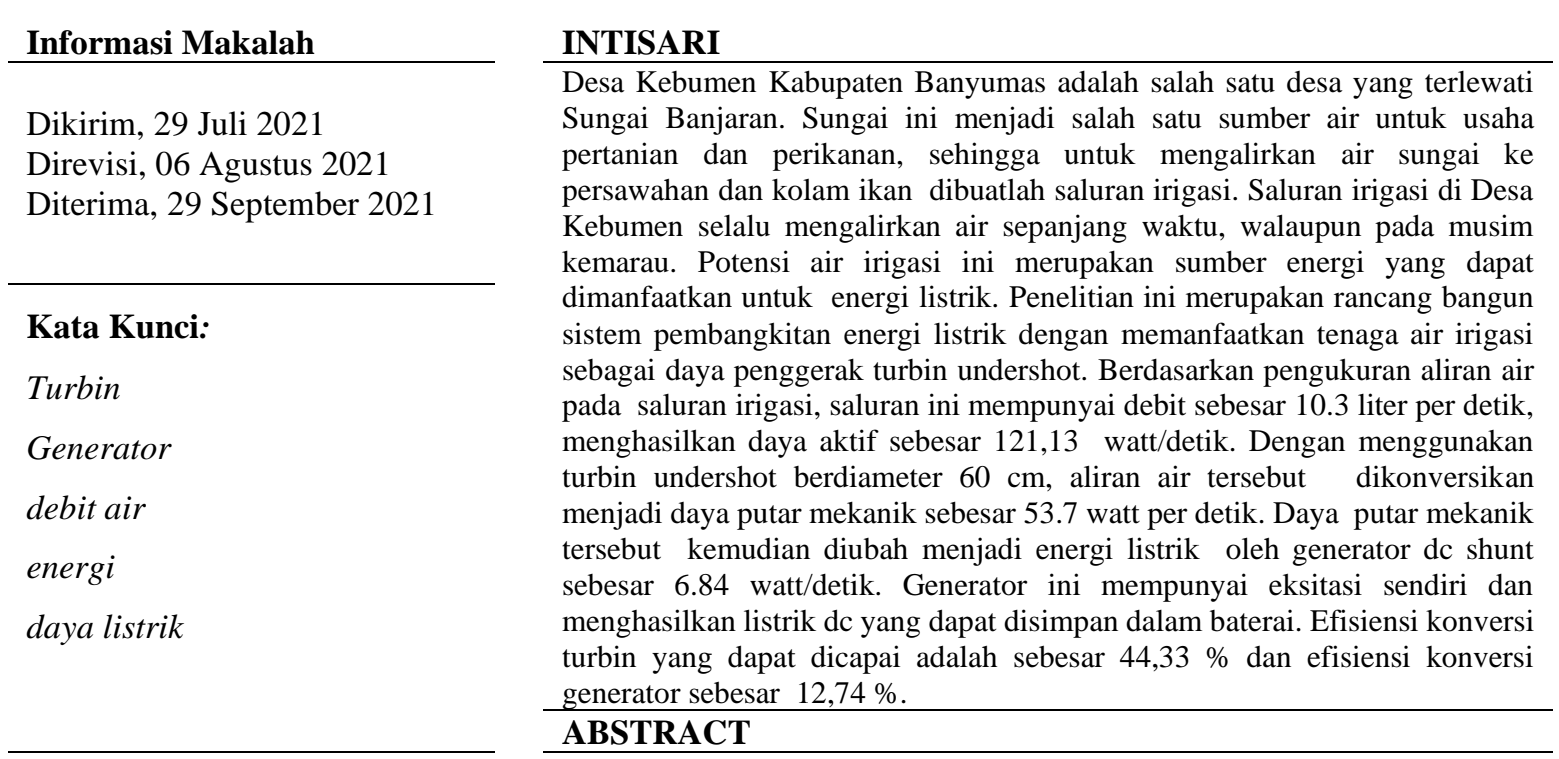

\section{Keyword:}

Turbine

Generator

water discharge

energy

electrical power
Kebumen Village, Banyumas Regency is one of the villages that is crossed by the Banjaran River. This river is a source of water for agriculture and fisheries, so irrigation canals are made to drain river water into rice fields and fish ponds. Irrigation channels in Kebumen Village always flow water all the time, even during the dry season. The potential of irrigation water is an energy source that can be used for electrical energy. This research is a design of an electrical energy generation system by utilizing irrigation water power as the driving force of the undershot turbine. Based on measurements of water flow in the irrigation canal, this channel has a discharge of 10.3 liters per second, producing an active power of 121.13 watts/second. By using an undershot turbine with a diameter of $60 \mathrm{~cm}$, the water flow is converted into mechanical rotational power of 53.7 watts per second. The mechanical rotational power is then converted into electrical energy by a shunt dc generator of 6.84 watts/second. This generator has self-excitation and produces dc electricity which can be stored in batteries. Turbine conversion efficiency that can be achieved is $44.33 \%$ and generator conversion efficiency is $12.74 \%$.

\section{Korespondensi Penulis: \\ Winarso \\ Program Studi Teknik Elektro \\ Universitas Muhammadiyah Purwokerto \\ JL. Raya Dukuhwaluh Purwokerto, 53182 \\ Email: ewinarso@gmail.com}




\section{Pendahuluan}

Negara Indonesia adalah negara yang sedang berkembang ditandai dengan naiknya jumlah penduduk dan pembangunan infrastruktur di setiap pelosok negeri seperti jalan raya, pasar modern, apartemen,bandara, pelabuhan dan lainnya. Pembangunan infrastruktur tersebut tidak lepas dari kebutuhan energi listrik yang terus meningkat. Energi listrik yang dihasilkan oleh sistem kelistrikan di negara kita sebagian besar masih menggunakan energi fosil yaitu jenis batubara, akan tetapi isu yang berkembang saat ini menjadi masalah besar yaitu pencemaran lingkungan dan menimbulkan efek rumah kaca. Untuk itu kebijakan pemerintah kita memberdayakan energi terbarukan, seperti energi matahari,energi angin, energi biogas dan energi potensial air.[1]

Demikian juga di negara lain seperti Negara India dengan jumlah penduduk mencapai 1.8 milyar dan pertumbuhan ekonomi 8-9\% telah meningkatkan kebutuhan energi listriknya mencapai 400 persen dan untuk menyelesaikan masalah energi tersebut dengan mengoptimalkan potensi tenaga air atau hydropower. [2]

Pembangkit tenaga air dianggap sebagai salah satu sumber energi terbarukan yang penting. Energi terbarukan adalah kontributor terbesar kedua untuk produksi listrik global setelah bahan bakar fosil. Pembangkit listrik tenaga air menghadirkan beberapa keunggulan dibandingkan sebagian besar sumber tenaga listrik lainnya. Ini termasuk tingkat keandalan yang tinggi, teknologi terbukti, efisiensi tinggi (sekitar 90\%), biaya operasi dan pemeliharaan yang sangat rendah, fleksibilitas dan kapasitas penyimpanan yang besar. [3]

Energi potensial air merupakan salah satu energi yang paling murah dalam operasionalnya sebagai pembangkit energi listrik, seperti pembangkit listrik tenaga pikohidro (PLTPH). Pembangkit listrik Pikohidro yaitu pembangkit listrik tenaga air yang dapat memproduksi listrik antara 100 watt sampai $5 \mathrm{~kW}$. Turbin air merupakan alat pengubah energi potensial air menjadi energi mekanik yang dapat dimanfaatkan sebagai penggerak generator. [4]

Pembangkit listrik tenaga piko hidro menggunakan turbin overshot merupakan suatu pembangkit listrik yang memanfaatkan aliran irigasi yang memiliki head yang rendah sebagai tenaga penggeraknya.[5]. Untuk mendukung sistem pembangkitan tenaga listrik pikohidro digunakan jenis genarator dc dengan eksitasi shunt yang dilengkapi dengan baterai penyimpan, tujuannya adalah agar tegangan listrik yang dihasilkan oleh pembangkit listrik pikohidro cukup stabil walaupun debit air fluktuatif. [6]. Pembangkit listrik tenaga alternatif pikohidro dengan generator dc yang dilengkapi dengan baterai dan inverter ac 220 volt dapat digunakan sebagai sumber energi listrik bagi peralatan listrik seperti lampu, televisi dan alat komunikasi. [7]

Penelitian yang dilakukan oleh Efrita Arfa Zuliari dan Ali Khomsah tentang perencanaan turbin crossflow sudu bambu sebagai pembangkit listrik tenaga pikohidro kapasitas 200 Watt. Hasil dari pengujian ini pada beban nol output tegangan maksimum sebesar 223 Volt, pada rasio pulley 1:4,5 dan daya aktual serta efisiensi total maksimal masing-masing sebesar 74,04 watt dan 23,3\%.[8]. Hasil studi pembangkit listrik pikohidro dengan konsep hydrocat pada aliran jalur irigasi di Desa Karang Cegak Kecamatan Kutasari Kabupaten Purbalingga adalah dapat menghasilkan daya listrik sebesar 0,1836 Watt, 0,1718 Watt, 0,1671 Watt, dan 0,165 Watt.[9]

Penelitian ini adalah memanfaatkan potensi air saluran irigasi pada Desa Kebumen untuk sumber listrik lampu penerangan dilokasi wisata embung maron. Penelitian ini menggunakan referensi turbin jenis overshot yang pernah dilakukan oleh syaiful dkk tahun 2020. Dengan memperbesar diameter turbin overshot dan generator dc shunt serta melengkapi baterai dan inverter maka daya listrik yang dihasilkan oleh sistem pikohidro ini diharapkan dapat mensuplai penerangan lokasi wisata embung air Desa Kebumen.

\section{METODOLOGI PENELITIAN}

\subsection{Alur Penelitian}

Penelitian sistem pikohidro ini dimulai dengan mempelajari beberapa jurnal maupun naskah publikasi yang berkaitan dengan topik penelitian. Identifikasi masalah yang dimunculkan pada penelitian ini dilaksanakan saat referensi yang dibutuhkan dianggap telah mencukupi, selanjutnya lihat alur penelitian berikut : (gambar 1.) 


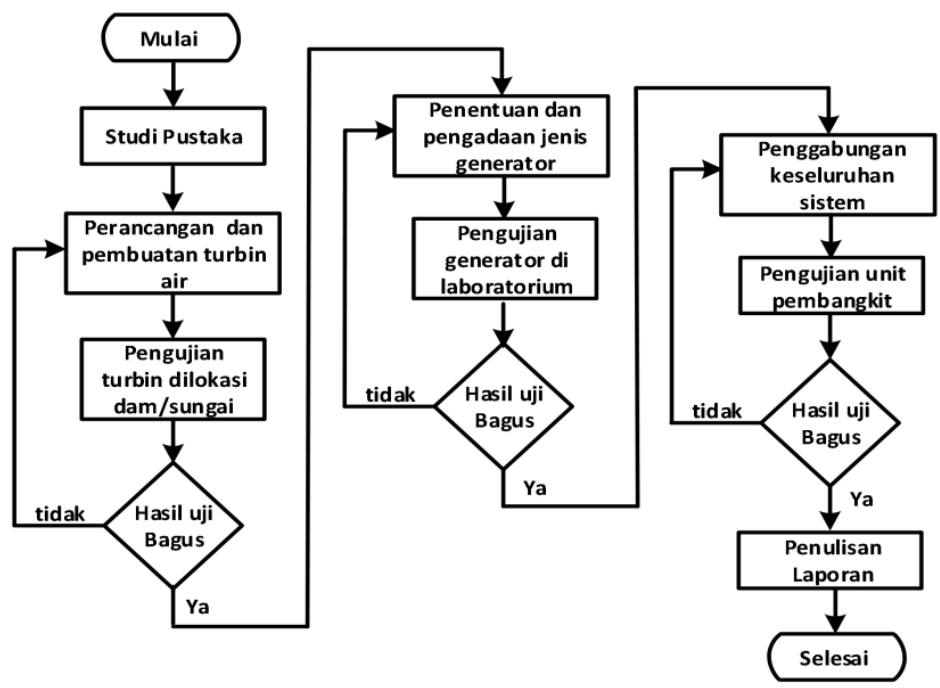

\subsection{Lokasi Penelitian}

Gambar 1. Alur Penelitian

Lokasi penelitian dilakukan di Laoratorium Mesin Listrik Prodi Teknik Elektro dan di lokasi wisata Embung Maron dusun satu Desa Kebumen Kecamatan Baturaden Kabupaten Banyumas 53151 Propinsi Jawa Tengah, lihat gambar 2 .
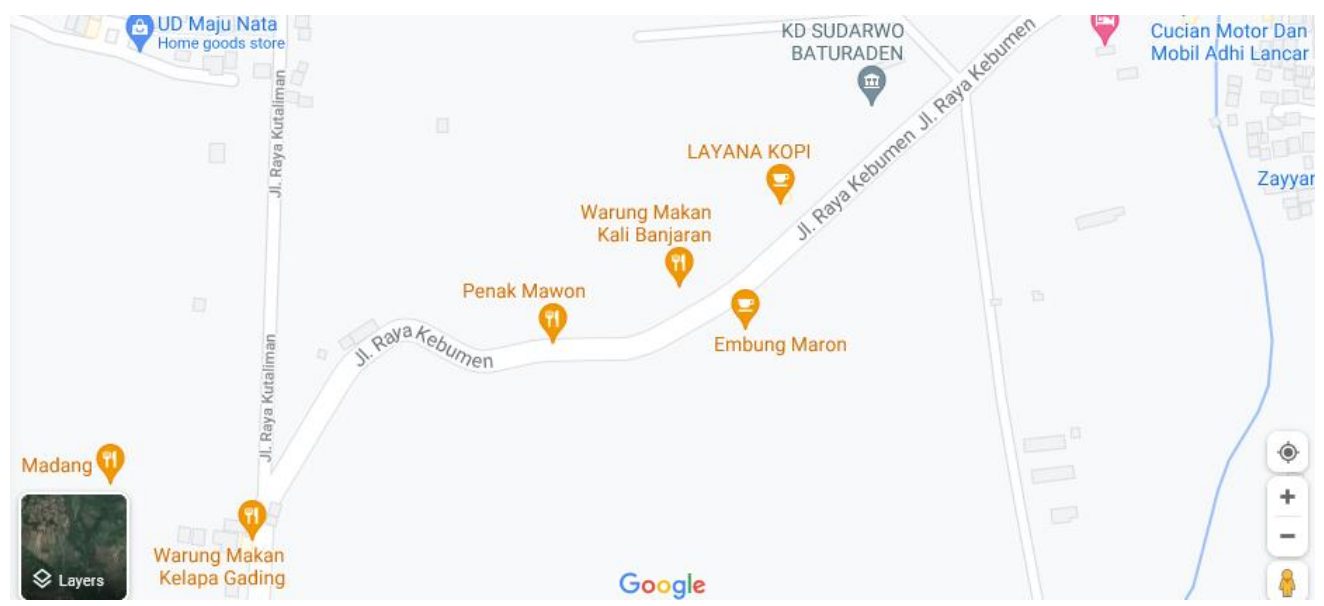

Gambar 2. Lokasi Penelitian Embung Maron

Sumber :https://www.google.com/maps/place/Embung+Maron/@-7.4026452,109.2115687,13

\subsection{Data Penelitian}

Data yang digunakan dalam penelitian ini adalah sebagai berikut :

1) Data pemgukuran lebar irigasi dan kedalaman irigasi, lihat tabel 1. berikut :

Tabel 1. Hasil Pengukuran lebar dan dalam irigasi

\begin{tabular}{cccccc}
\hline Titik & Lebar $(\mathbf{L})$ & \multicolumn{4}{c}{ Kedalaman air } \\
& (Meter) & H1 & H2 & H3 & H Rata-Rata \\
\hline Titik 1 & 0,48 & 0,30 & 0,31 & 0,29 & 0,30 \\
Titik 2 & 0,50 & 0,29 & 0,30 & 0,31 & 0,30 \\
Titik 3 & 0,46 & 0,28 & 0,30 & 0,31 & 0,29 \\
Titik 4 & 0,51 & 0,30 & 0,27 & 0,22 & 0,26 \\
Titik 5 & 0,47 & 0,31 & 0,32 & 0,26 & 0,29 \\
Jumlah & 2.42 & & & & 1.44 \\
Rata-Rata & $\mathbf{0 , 4 8}$ & & & & $\mathbf{0 , 2 9}$
\end{tabular}

2) Data pengukuran kecepatan aliran air irgasi, lihat tabel 2 berikut :

Tabel 2. Hasil Pengukuran kecepatan air 


\begin{tabular}{|c|c|}
\hline Pengulangan & $\begin{array}{l}\text { Waktu Pengukuran } \\
\text { Saluran Irigasi (detik) }\end{array}$ \\
\hline Pengukuran 1 & 29,1 \\
\hline Pengukuran 2 & 28,4 \\
\hline Pengukuran 3 & 29,0 \\
\hline Pengukuran 4 & 28,5 \\
\hline Pengukuran 5 & 29,1 \\
\hline Jumlah & 144,1 \\
\hline Rata-Rata & 28,82 \\
\hline
\end{tabular}

3) Data Pengujian Generator shunt, lihat tabel 3 berikut :

Tabel 3. Hasil Pengukuran kecepatan air

\begin{tabular}{rcc}
\hline No & $\begin{array}{c}\text { Kecepatan generator } \\
(\mathbf{~ r p m})\end{array}$ & $\begin{array}{c}\text { Tegangan output } \\
\text { ( volt })\end{array}$ \\
\hline 1 & 200 & 11.95 \\
2 & 240 & 12.28 \\
3 & 280 & 12.56 \\
4 & 320 & 12.98 \\
5 & 360 & 13.27 \\
6 & 400 & 13.65 \\
7 & 440 & 13.97 \\
8 & 500 & 14.55 \\
9 & 600 & 15.35 \\
10 & 700 & 16.25 \\
11 & 800 & 17.30 \\
12 & 900 & 18.55 \\
13 & 1000 & 19.65 \\
\hline
\end{tabular}

\subsection{Analisa Data}

Dari tabel 1 didapatkan luas rata rata saluran irigasi (a) adalah $0.139 \mathrm{~m}^{2}$ dan dari tabel 2 didapatkan kecepatan aliran air irigasi rata rata dengan panjang sample 30 meter, adalah :

$$
\mathrm{v}=\frac{30}{28,82}=1.04 \text { meter/detik. }
$$

Sehingga dari data luas sungai dan kecepatan aliran air maka dapat diketahui debit air irigasi seperti persamaan (Q) :

$$
\begin{aligned}
& \mathrm{Q}=\mathrm{a} \times \mathrm{v} \\
& =0.139 \times 1.04 \\
& =0,145 \mathrm{~m} 3 / \text { detik }=145 \text { liter } / \text { detik }
\end{aligned}
$$

Energi kinetik air irigasi akan digunakan untuk menggerakan turbin. Untuk mendapatkan energi konversi yang maksimum maka dipilih jenis turbin Undershot. Turbin undershot bekerja bila air yang mengalir, menghantam dinding sudu yang terletak pada bagian bawah dari kincir air.Tipe ini cocok dipasang pada perairan rendah pada daerah yang rata. Pada penelitian ini debit air terukur adalah $0,145 \mathrm{~m}^{3 /}$ detik atau 145 liter/detik dengan kecepatan air adalah 1,04 meter/detik. Sehingga besarnya daya potensial air :

$$
E_{K}=\frac{1}{2} m \cdot v^{2}=\frac{1}{2} \cdot 997 \cdot 1 \cdot 04^{2}=539.17 \text { joule }=539,17 \text { watt-detik }
$$

Untuk dapat mengubah energi kinetik air menjadi energi listrik maka dimensi turbin undershot adalah :

$$
\begin{aligned}
& \text { Diameter turbin (D) } \quad=60 \mathrm{~cm} \\
& \text { Jari jari turbin ( } r \text { ) } \\
& =\frac{1}{2} \cdot \mathrm{D}=\frac{1}{2} \cdot 60=30 \mathrm{~cm} \\
& \text { Luas sudu turbin } \\
& =110 \mathrm{~cm}^{2}, 220 \mathrm{~cm}^{2}, 600 \mathrm{~cm}^{2} \\
& \text { Putaran poros turbin }\left(\mathrm{n}_{\mathrm{p}}\right) \\
& =\frac{v \cdot 60}{2 . \pi \cdot r}=\frac{1.04 .60}{2.3,14.0 .3}=33.12 \mathrm{rpm} \\
& \text { Kecepatan tangensial }(\mathrm{U}) \quad=\frac{\pi \cdot D \cdot p}{60}=\frac{3 \cdot 14 \cdot 0,6 \cdot 33,12}{60}=1,04 \mathrm{~m} / \mathrm{s} \\
& \text { Kecepatan sudu turbin }(\omega) \quad=\frac{U}{r}=\frac{1,04}{0,3}=3,47 \mathrm{rad} / \mathrm{detik} \\
& \text { Masa air }(\mathrm{m}) \quad=\mathrm{Q} \cdot \rho \\
& =0,145.997
\end{aligned}
$$




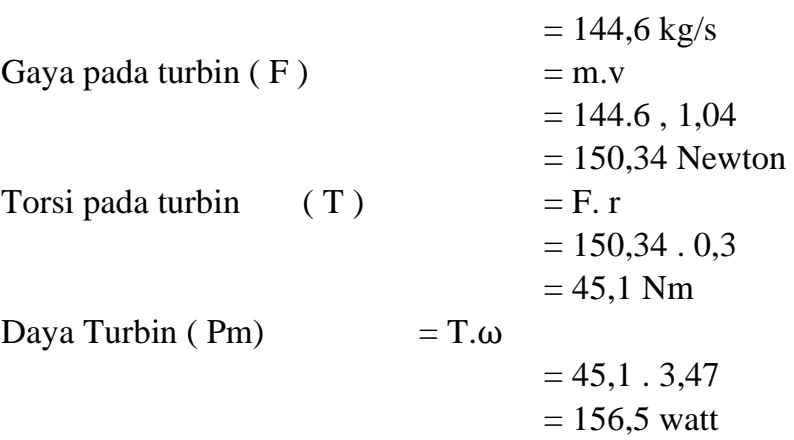

Dari perhitungan diatas, dengan luas aliran irigasi $0,48 \mathrm{~m}^{2}$, kecepatan aliran air 1,04 m/s , diameter turbin 0,6 meter, maka di dapatkan daya mekanik turbin sebesar 156,74 watt. Untuk mendapatkan daya konversi yang maksimum maka di buat beberapa sudu turbin, yaitu :

a. Sudu turbin luas $110 \mathrm{~cm}^{2}=10 \times 11=0.1 \times 0.11=0,011 \mathrm{~m}^{2}$

$$
\begin{aligned}
\text { Maka daya guna tubin } & =\frac{0,011}{0,27} \times 100 \%=4,07 \% \\
& =4,07 \% \times 303,74 \\
& =12,36 \text { watt }
\end{aligned}
$$

b. Sudu turbin luas $220 \mathrm{~cm}^{2}=20 \times 11=0.2 \times 0.11=0,022 \mathrm{~m}^{2}$

Maka daya guna tubin

$$
\begin{aligned}
& =\frac{0,022}{0,27} \times 100 \%=8,14 \% \\
& =8,14 \% \text { x } 303,74 \\
& =24,74 \text { watt }
\end{aligned}
$$

c. Sudu turbin luas $600 \mathrm{~cm}^{2}=40 \times 15=0.4 \times 0.15=0,06 \mathrm{~m}^{2}$

$$
\begin{aligned}
\text { Maka daya guna tubin } & =\frac{0,06}{0,27} \times 100 \%=22,22 \% \\
& =22,22 \% \times 303,74 \\
& =67,49 \mathrm{watt}
\end{aligned}
$$

Setelah menentukan dimensi turbin dan lebar sudu dan membuat prototipe turbin, maka dilakukan pengujian turbin. Data hasil pengujian turbin dapat dilihat gambar 3.

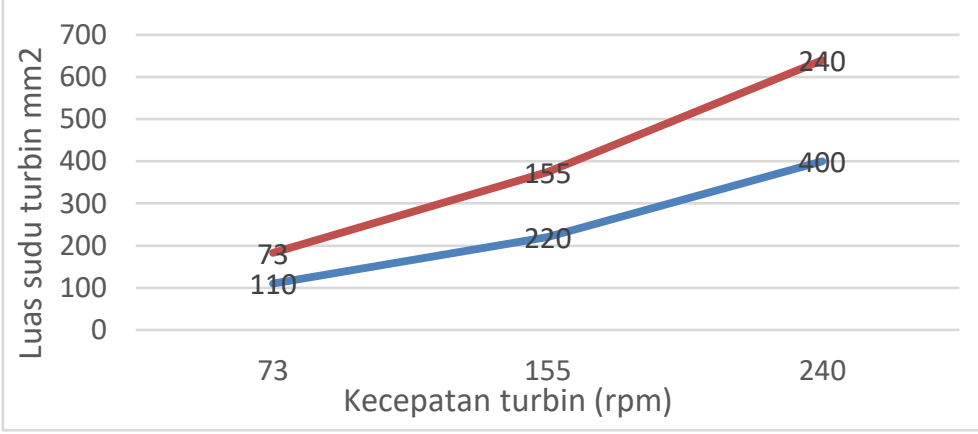

Gambar 3. Hubungan luas sudu turbin dengan kecepatan

Dari hasil pengukuran kecepatan turbin diperoleh data kecepatan yang masih cukup rendah dibandingkan kebutuhan kecepatan minimal generator dc eksitasi luar yaitu $1500 \mathrm{rpm}$, hal ini dikarenakan kecepatan aliran air rata-rata cukup rendah yaitu 1.04 meter/detik. Untuk mengatasi masalah tersebut langkah yang dilakukan adalah mengalirkan air melalui pipa sepanjang 60 meter dengan diameter 4 inchi dan hasil pengukuran debit secara langsung diperoleh $\mathrm{Q}=10,3$ liter/detik. Dari hasil pengukuran debit air dengan pipa diameter 4 inchi, maka diperoleh kecepatan air seperti persamaan berikut :

dimana :

$$
\mathrm{Q}=\mathrm{a} \times \mathrm{v}
$$

a adalah luas pipa yaitu $=\pi \cdot \mathrm{r}^{2}=3 \cdot 14 \cdot 0.0508^{2}=0.0081 \mathrm{~m}^{2}$

$\mathrm{Q}$ adalah debit air yaitu 10,3 liter/detik atau $=0.0155 \mathrm{~m}^{3} /$ detik

Sehingga besarnya kecepatan aliran air adalah : 


$$
\mathrm{v}=\frac{Q}{a}=\frac{0.0103 \mathrm{~m}^{3} / \text { detik }}{0.0081 \mathrm{~m}^{2}}=1,27 \text { meter } / \text { detik }
$$

Dengan mengubah daya masuk turbin dengan pipa 4 inchi didapatkan kecepatan air sebesar 1,27 meter/detik dan diperoleh kecepatan turbin (n) tanpa beban sebesar $=587 \mathrm{rpm}$ dan pada saat berbeban $355 \mathrm{rpm}$. Sehingga parameter perhitungan daya turbin adalah :

$\begin{array}{ll}\text { Daya aktif tenaga potensial air }(\mathrm{P}) & =\rho \cdot \mathrm{Q} \cdot \mathrm{g} \cdot \mathrm{h} \\ & =1 \cdot 000 \times 0,0103 \times 9,8 \times 1,2 \\ & =121,13 \mathrm{watt} \\ \left.\text { Daya Turbin tanpa beban( } \mathrm{P}_{\mathrm{T}}\right) & =\frac{2 \cdot \pi \cdot n_{T}}{60} \\ & =\frac{2.3,14 \cdot 587}{60} \\ & =61,44 \mathrm{watt} \\ & =\frac{2 \cdot \pi \cdot n_{T}}{60} \\ \text { Daya Turbin berbeban } & =\frac{2.3,14 \cdot 355}{60} \\ & =37,15 \mathrm{watt}\end{array}$

\section{HASIL DAN PEMBAHASAN}

3.1 Hasil Pengujian Generator shunt berbeban

Pada pengujian generator shunt berbeban dilakukan pada kecepatan $430 \mathrm{rpm}$ sesuai data saat pengujian kecepatan turbin dalam keadaan berbeban, tegangan generator mengalami penurunan karena beban yang terus naik dan kecepatan kontsan hal ni disebabkan daya aktif masuk generator lebih kecil dibanding daya pembebanan generator, sehingga kecepatan generator melemah dan tegangan akan turun, lihat gambar 4. berikut ini :

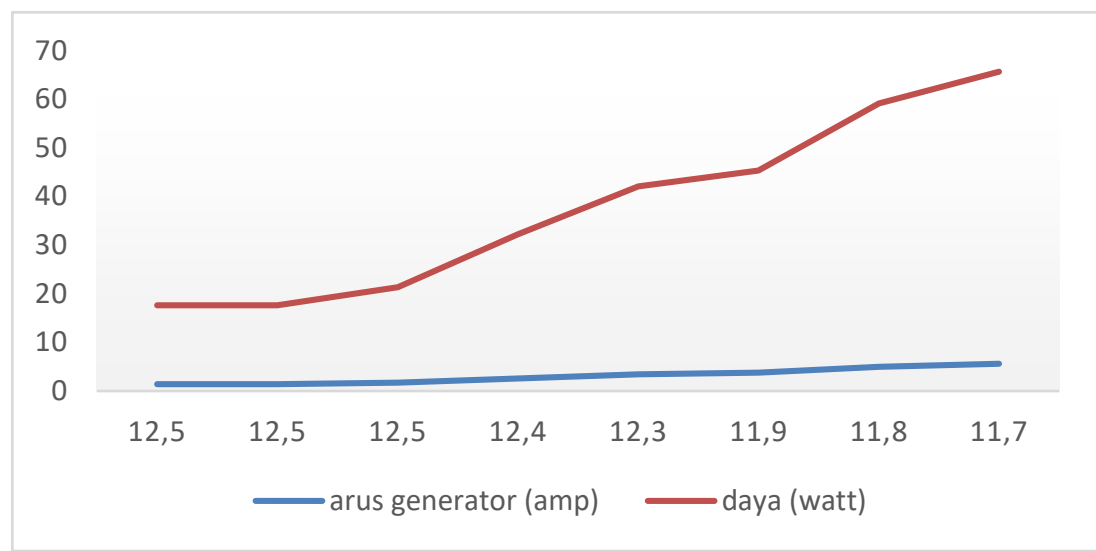

Gambar 4. Pengujian generator shunt berbeban kecepatan konstan

\subsection{Hasil Pengujian Generator shunt berbeban inverter dan lampu LED}

Pengujian generator shunt berbeban inverter juga dilakukan pada kecepatan $430 \mathrm{rpm}$ sesuai data saat pengujian kecepatan turbin dalam keadaan berbeban, tegangan generator mengalami penurunan karena beban yang terus naik dan kecepatan kontsan hal ni disebabkan daya aktif masuk generator lebih kecil dibanding daya pembebanan generator, sehingga kecepatan generator melemah dan tegangan akan turun. Demikian juga tegangan pada inverter mengalami penurunan karena pembebanan terus dinaikan sehingga mempengaruhi kecepatan generator, lihat gambar 5, berikut ini : 


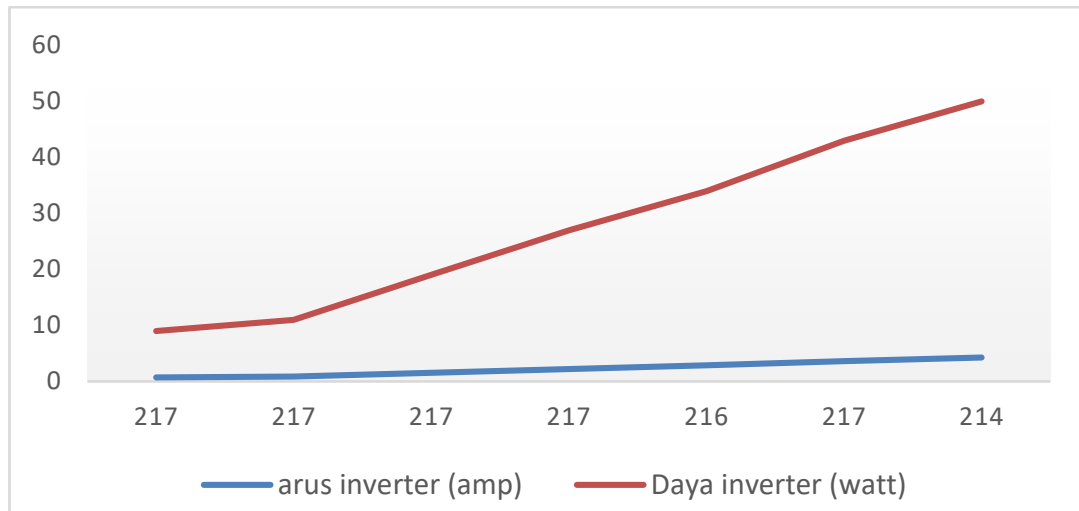

Gambar 5. Pengujian generator shunt berbeban inverter dan lampu led

\subsection{Hasil Pengujian Sistem pikohidro}

\subsubsection{Pengujian turbin tanpa beban dan berbeban}

Pengujian ini dilakukan setelah sistem pikohidro terpasang pada saluran irigasi. Turbin diberikan daya aktif dari saluran irigasi melalui pipa pvc 4 inchi sesuai dengan debit 10,3 liter per detik dan menghasilkan putaran pada turbin rata-rata $512 \mathrm{rpm}$. Kemudian pengujian dilanjutkan dengan membebani turbin dengan generator shunt dan menghasilkan putaran pada generator sebesar $445 \mathrm{rpm}$ dengan tegangan 14,35 volt.

\subsubsection{Pengujian turbin dan generator berbeban lampu led}

Pengujian sistem pembangit listrik pikohidro dilakukan dengan memanfaatkan daya aktif dari saluran air pada irigasi Desa Kebumen serta menggunakan beban lampu led dua buah dengan daya 13 watt yang ada di lokasi wisata embung Desa Kebumen. Adapaun data pengukuran sistem pikohidro pada lokasi seperti pada tabel 5 . berikut ini :

Tabel 4. Data Pengukuran Sistem Pikohidro

\begin{tabular}{|c|c|c|c|c|c|c|c|c|c|c|c|}
\hline \multirow{2}{*}{$\begin{array}{l}\mathrm{N} \\
\mathrm{o}\end{array}$} & \multirow[t]{2}{*}{ Jenis Pengujian } & \multicolumn{2}{|c|}{ Generator } & \multicolumn{2}{|c|}{ Energi } & \multicolumn{2}{|c|}{$\begin{array}{c}\text { Daya terpakai } \\
\text { sistem }\end{array}$} & \multirow{2}{*}{$\begin{array}{c}\text { Waktu } \\
\text { uji } \\
\text { (jam) }\end{array}$} & \multirow{2}{*}{$\begin{array}{c}\text { Energi } \\
\text { generator } \\
\text { watt-jam }\end{array}$} & \multirow{2}{*}{$\begin{array}{c}\text { Energi } \\
\text { baterai } \\
12 \times 32 \times 0.65 \\
\text { watt-jam }\end{array}$} & \multirow{2}{*}{$\begin{array}{c}\text { energi } \\
\text { terpakai } \\
\text { sistem } \\
\text { watt-jam }\end{array}$} \\
\hline & & $\begin{array}{l}\text { teg } \\
\text { volt }\end{array}$ & $\begin{array}{l}\text { arus } \\
\text { amp }\end{array}$ & $\begin{array}{c}\text { teg } \\
\text { volt }\end{array}$ & $\begin{array}{l}\text { arus } \\
\text { amp }\end{array}$ & $\begin{array}{l}\text { teg } \\
\text { volt }\end{array}$ & $\begin{array}{l}\text { arus } \\
\text { amp }\end{array}$ & & & & \\
\hline 1 & $\begin{array}{l}\text { Pengujian beban led } 13 \mathrm{w} \\
\text { dari jam } 13.00 \mathrm{sd} 14.00\end{array}$ & 12.7 & 0.48 & 12,6 & -1.13 & 12.6 & 1.42 & 1 & 6.13 & -14.24 & 17.892 \\
\hline 2 & $\begin{array}{l}\text { Pengujian tanpa beban } \\
\text { dari jam } 14.00 \mathrm{sd} 18.00\end{array}$ & 12.9 & 0.53 & 12.8 & -0.32 & 12.8 & 0.35 & 4 & 27.24 & -16.13 & 17.85 \\
\hline 3 & $\begin{array}{l}\text { Pengujian beban led } 13 \mathrm{w} \\
\text { dari jam } 18.00 \mathrm{sd} 05.00\end{array}$ & 12.7 & 0.48 & 12,6 & -1.13 & 12.6 & 1.42 & 11 & 67.37 & -156.62 & 196.812 \\
\hline \multirow[t]{5}{*}{4} & $\begin{array}{l}\text { Pengujian tanpa beban } \\
\text { dari jam } 05.00 \mathrm{sd} 13.00\end{array}$ & 12.9 & 0.53 & 12.8 & -0.32 & 12.8 & 0.35 & 8 & 54.48 & -32.64 & 35.7 \\
\hline & \multicolumn{8}{|l|}{ Total energi ( watt jam) } & 155.22 & -219.63 & 268.254 \\
\hline & \multicolumn{7}{|c|}{ Energi sistem PLTPH selama 24 jam adalah energi dari generator dan baterai : } & 404.8 & & watt-jam & \\
\hline & \multicolumn{7}{|c|}{ Energi yang terpakai oleh sistem selama 24 jam adalah : } & 268.3 & & watt-jam & \\
\hline & \multicolumn{7}{|c|}{ Sisa energi sistem setelah 24 jam adalah : } & 136.6 & & watt-jam & \\
\hline
\end{tabular}

Dari tabel 4., di peroleh informasi data pengujian sistem pembangkit listrik pikohidro, dimana energi yang digunakan untuk mensuplai sistem dalam kondisi tanpa beban adalah sebesar 6.84 watt detik dan untuk mensuplai sistem dalam kondisi berbeban adalah sebesar 17,89 watt detik. Energi yang di hasilkan oleh turbingenerator hanya 6.84 watt detik, sehingga untuk mensuplai beban listrik harus mengambil sebagian energi dari baterai. Energi yang dihasilkan oleh generator selama 24 jam adalah 155.22 watt-jam dan energi awal baterai adalah 249,5 watt-jam. Energi yang diserap oleh beban listrik sistem pikohidro selama 24 jam adalah 268,3 watt, sehingga energi sistem pikohirdo setelah 24 jam menjadi 164,16 watt jam. Energi yang tersisa sebesar 164,16 watt-jam dapat bertahan sekitar 12,6 jam untuk mensuplai lampu penerangan walaupun ditambahkan energi dari generator, hal ini disebabkan energi dari debit air tidak mampu memutar turbingenerator secara maksimal, akibatnya produksi energi listriknya menjadi sangat kurang untuk sistem ini. Kekurangan energi air pada sistem ini dikarenakan ketinggian muka air terhadap tubin hanya 1.2 meter 
sehingga daya aktif yang memutar turbin tidak mencapai putaran produktif generator yaitu sekitar $1000 \mathrm{rpm}$. Berikut kami informasikan laju energi pada sistem pikohidro seperti pada gambar 6., berikut ini :

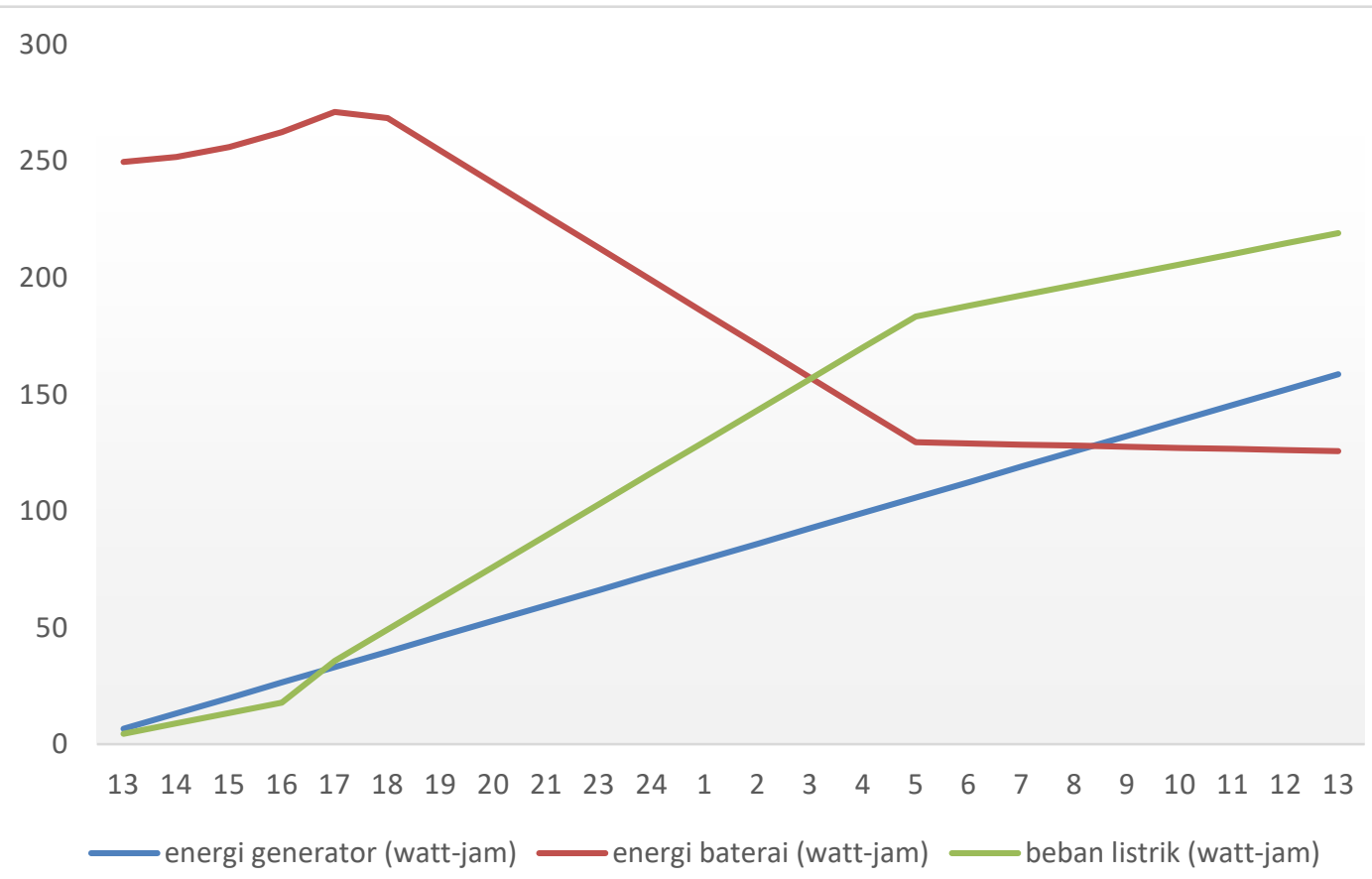

Gambar 5. Laju energi generator dan baterai serta energi yang terserap pada lampu led pada sistem pikohidro.

\section{KESIMPULAN}

Dengan memanfatkan potensi air irigasi yang dialirkan ke turbin dan kemudian energi kinetik turbin dikonversi menjadi energi listrik oleh generator, maka energi listrik bisa didapatkan secara mudah dan murah serta ramah lingkungan. Penelitian pembangkit listrik pikohidro ini menggunakan turbin undershot dan generator dc shunt yang digunakan untuk mengkonversi energi aliran irigasi yang mempunyai debit 10,3 liter/detik menjadi energi listrik. Aliran air ini mempunyai potensi daya aktif sebesar 121,3 watt/detik, kemudian energi air tersebut dikonversi menjadi energi gerak oleh turbin air undershot sebesar 37,15 watt/detik. Daya aktif keluaran turbin tersebut dikonversi menjadi listrik dc oleh generator dc shunt sebesar 6,84 watt/detik. Energi listrik ini disimpan dalam baterai dengan kapasitas pengisian per hari 164,16 watt, kemudian dengan inverter $d c$ to ac energi listrik yang tersimpan dalam baterai diubah menjadi listrik ac 220 volt, $50 \mathrm{hz}$ untuk mensuplai beban lampu led 13 watt selama 12,6 jam. Dengan pengaturan besarnya beban listrik dan waktu pemakaian maka energi listrik yang dihasilkan oleh pembangkit listrik pikohidro ini dapat dimanfaatkan sebagai sumber listrik untuk penerangan.

\section{UCAPAN TERIMAKASIH}

Atas terselenggaranya penelitian ini, peneliti mengucapkan terima kasih kepada 1. LPPM UMP yang telah mendanai penelitian ini.

2. Kepala Desa dan staff Desa Kebumen Kecamatan Baturraden yang telah mengizinkan dan membantu peneliti dalam melakukan penelitian ini.

\section{DAFTAR PUSTAKA}

[1] Djiteng Marsudi, Ir (2005).,"Pembangkitan Energi Listrik", Ciracas Jakarta, Penerbit Erlangga.

[2] Garg, P. (2012). Energy scenario and vision 2020 in India. Journal of Sustainable Energy and Environment, 3(1), 7-17.

[3] Kiki Kananda, Dean Corio, Efa Maydhona S.(2020)," Simulation of Turbines Design For Hidropower In Way Laai and Way Lami Pesisir Barat District, Lampung Province, Jurnal ECOTIPE, Volume 7, No.1, April 2020, Hal. 7-11 p-ISSN 2355-5068, e-ISSN 2622-4852 
[4] Arismunandar, A. Dan Susumu Ku. (1975). Teknik Tenaga Listrik : Pembangkit Dengan Tenaga Air. Jilid I. Jakarta. PT. Pradnya Paramita.

[5] K. Jamlay, L.Sule, and D.Hasan,(2016)“Analisis perilaku aliran terhadapkinerja roda air arus bawah untuk pembangkit listrik skala pikohidro,” Din. Tek. Mesin J. Keilmuan Dan bTerap. Tek. Mesin, vol. 6, no. 1 ,

[6] Zuhal,(2000) “Dasar Teknik Tenaga Listrik dan elektronika daya”, Jakarta, PT Gramedia Pustaka Utama.

[7] M. N. H. Najuta,(2019) "Rancang Bangun Pembangkit Lsitrik Alternatif Dengan Bantuan Pully dan Belt Motor DC sebagai Penggerak Alternator," Universitas Muhammadiyah Palembang.

[8] Efrita Arfa Zuliari dan Ali Khomsah.(2014). Perencanaan Turbin Cross Flow Sudu Bambu Sebagai Pembangkit Listrik Tenaga Pico Hydro Kapasitas 200 Watt, Seminar Nasional Sains dan Teknologi Terapan II 2014 ISBN : 978 60298569-1-0 Institut Teknologi Adhi Tama Surabaya.

[9] Syaiful Anwar (2020)," Rancang Bangun Sistem Pembangkit Listrik Tenaga Air Menggunakan Konsep Hydrocat" RESISTOR (Elektronika Kendali Telekomunikasi Tenaga Listrik Komputer) Vol. 4 No. e-ISSN : 2621-9700, p-ISSN : 2654-2684 
